\title{
Polychaetes from Aysén Fjord, Chile: distribution, abundance and biogeographical comparison with the shallow soft-bottom polychaete fauna from Antarctica and the Magellan Province*
}

\author{
J. I. CAÑETE ${ }^{1,2}$, G. L. LEIGHTON ${ }^{1}$ and F. F. AGUILERA ${ }^{1}$ \\ ${ }^{1}$ Instituto de Oceanología, Universidad de Valparaíso, Casilla 13-D, Viña del Mar, Chile \\ ${ }^{2}$ Present address: Departamento de Ciencias y Recursos Naturales, Facultad de Ciencias, Universidad de Magallanes, \\ Casilla 113-D, Punta Arenas, Chile; icanete@aoniken.fc.umag.cl
}

\begin{abstract}
SUMMARY: This paper analyzes the composition, abundance and biogeographical relationship of the benthic polychaetes collected in three shallow subtidal locations (mouth of Cuervo and Condor rivers and Acantilada Bay) from Aysen Fjord, $\mathrm{AF}$, Chile $\left(45^{\circ} \mathrm{S}, 73^{\circ} \mathrm{W}\right)$, and provides a comparison with data on shallow soft-bottom polychaetes from Antarctica and other locations of the Magellan Province: Dalcahue Channel, DC ( $\left.42^{\circ} 22^{\prime} \mathrm{S}, 73^{\circ} 39^{\prime} \mathrm{W}\right)$, Puerto Cisnes, Puyuhuapi Channel, PC

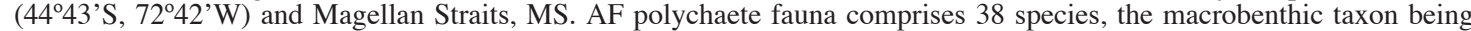
most representative in terms of abundance and species richness. The importance of polychaetes seems to be higher in fjords than in channels. Low numbers of common species were detected among DC, PC, MS and AF, indicating differences along the influence area of the Cape Horn Current or along the Magellan Province. The polychaetes from AF show low affinities with Antarctica; maximum number of common species was observed with the Antarctic Peninsula, whereas the lowest values were recorded from locations in the Ross and Weddell Seas. Coincidence in some ecological attributes between AF and Antarctica indicate that polychaetes may play an important and similar ecological role in both environments.
\end{abstract}

Key words: Polychaeta, biodiversity, biogeography, Chile, Magellan Province, Antarctica.

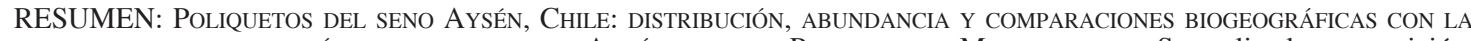

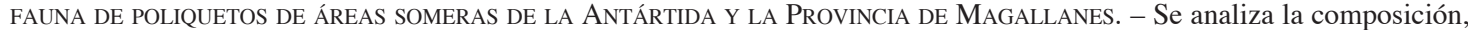
abundancia y relaciones biogeográficas de poliquetos bentónicos recolectados en tres localidades someras (desembocadura de los ríos Cuervo y Cóndor y Bahía Acantilada) del Seno Aysén, SA, Chile (45 $\left.\mathrm{S}, 73^{\circ} \mathrm{O}\right)$, y se efectúa una comparación con los poliquetos de la Antártida y otras localidades de la Provincia de Magallanes: Canal Dalcahue, CD ( $42^{\circ} 22^{\prime}$ S

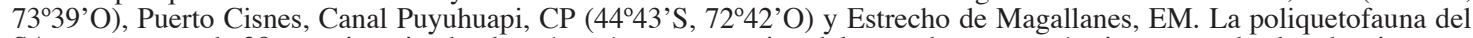
SA se compone de 38 especies, siendo el taxón más representativo del macrobentos en términos tanto de abundancia como de riqueza de especies. La importancia de los poliquetos parece mayor en fiordos que en canales. Se detectaron escasas afinidades entre CD, CP, EM y SA, indicando diferencias geográficas del papel de los poliquetos en la Provincia de Magallanes o en el área influenciada por la corriente del Cabo de Hornos. Existen escasas afinidades entre los poliquetos del SA y la Antártida; el mayor número de especies comunes fue compartido con la Península Antártica, mientras que ocurría lo contrario con localidades de los Mares de Ross y Weddell. La similitud de algunos atributos ecológicos entre SA y la Antártida sugieren que los poliquetos juegan un papel ecológico similar en ambos ambientes.

Palabras clave: Polychaeta, biodiversidad, biogeografía, Chile, Provincia de Magallanes, Antártida.

\footnotetext{
*Accepted March 9, 1999.
} 


\section{INTRODUCTION}

The southern end of South America represents one of the most interesting Subantarctic areas from both a biogeographical and an ecological point of view. The relative closeness of this area to the Antarctic continent, which is separated by the Scotia Arc, and the continuity with the coast of the American continent, define this zone as a crossroad in terms of biogeography and biodiversity. The peculiar hydrological conditions of the West Wind Drift current which influences the eastern Pacific border to the south of $40^{\circ} \mathrm{S}$ (limit of the Subtropical Convergence) to Cape Horn (latitude 55'59'S) through the Cape Horn Current (CHC), might affect the marine biota producing affinities in biodiversity, composition, abundance and geographical similarities between Chiloé Island, the Magellan Straits and Cape Horn including the Patagonian shelf and the Falkland Islands, and dissimilarities between the Magellan Province and Antarctic benthic communities (Moyano, 1982; Brattström and Johanssen, 1983; Arntz et al., 1994; Arntz and Gorny, 1996; Arntz and Ríos, 1997).

Between 1990 and 1997 the Instituto de Oceanología of the University of Valparaíso, Chile, carried out various studies in the Aysen Fjord, considering the oceanography (Sievers and PradoFiedler, 1994; Sievers and Vega, 1996) as well as the structure and biodiversity of pelagic (Avaria et al., 1996) and benthic communities (Leighton et al., 1994). In the latter, it was observed that polychaetes represent an important taxon in terms of number of species and abundance in shallow waters. This taxon is quite unknown (Wesenberg-Lund, 1962; Hartmann-Schröder, 1962,1965), although according to Rozbaczylo et al. (1997) there are 182 species distributed in 10 orders, 35 families and 112 genera only in the area between $49^{\circ} \mathrm{S}$ and $55^{\circ} 59^{\prime} \mathrm{S}$.

In this paper we analyze the composition, species richness, abundance and the biogeographical affinities of the polychaete fauna from Aysen Fjord, Magellan Province (Moyano, 1982; Brattström and Johanssen, 1983). A comparison is made with some published data on the shallow, subtidal soft-bottom polychaete fauna from Antarctica (south of the Antarctic Convergence; $\sim 60^{\circ} \mathrm{S}$ ), and other sites of the Magellan Province (Dalcahue, $42^{\circ} 22^{\prime} \mathrm{S}$,

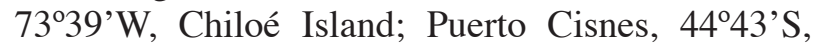
$72^{\circ} 42^{\prime} \mathrm{W}$; and Magellan Straits).

\section{MATERIAL AND METHODS}

Aysen Fjord is one of numerous fjords of southern Chile (Fig. 1 and 2a). It has an east-west orientation, is $72 \mathrm{~km}$ long, and connected with the channels Moraleda and Costa. As for others fjords and channels in this area, low salinity has been reported for the Aysen Fjord due to numerous water sheds that flow into the fjord, in particular the Aysen River, which is located at the fjord head. The effects of the continuous rain $\left(\sim 2500 \mathrm{~mm} \mathrm{~m}^{-2}\right.$ per year) are also important. Shallow bottoms are scarce in the fjord, which in its center has a depth of $>350 \mathrm{~m}$. In general, shallow soft bottoms are located near the

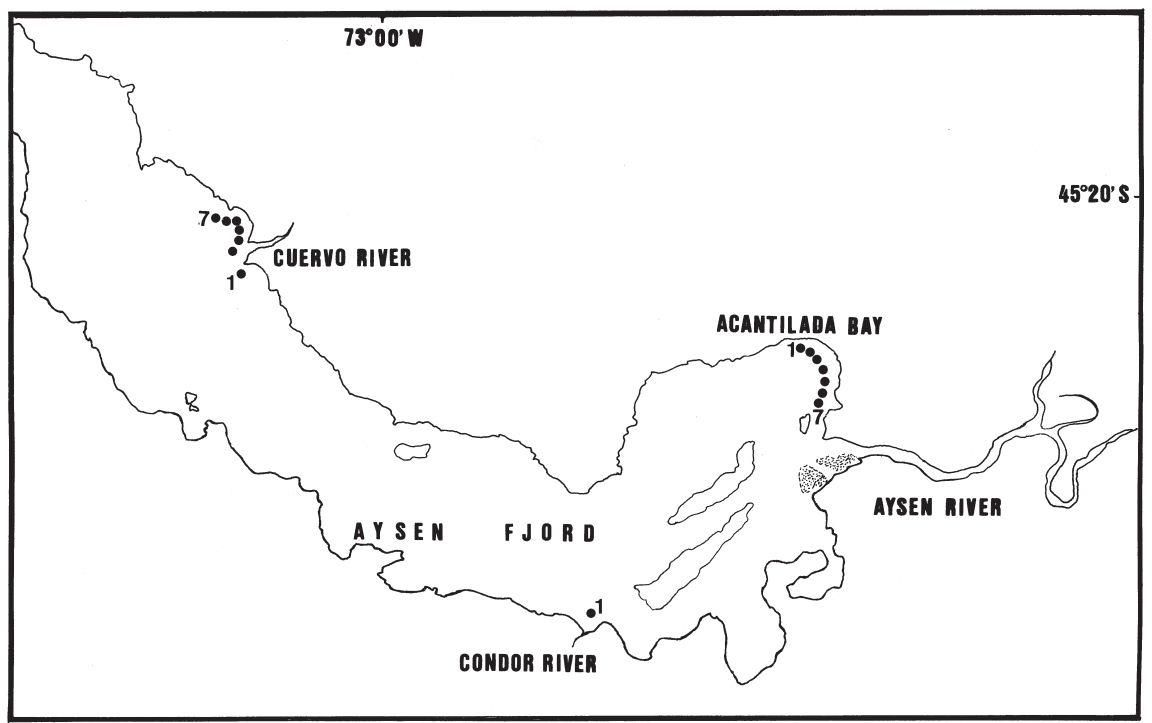

FIG. 1. - Map showing the three study sites (Cuervo, Condor and Acantilada Bay) located along Aysen Fjord, southern Chile. The black circles show the sampling stations at each study site. 
mouth of small rivers such as Condor and Cuervo, where the present study took place (Fig. 1). In Acantilada Bay, greatest depths and cliffs are present close to the coastal line, and the nearest site is located at the mouth of Aysen River (Fig. 1). During the period of study, salinity clearly showed a two layer structure separated by a halocline of variable intensity (10 m depth). The low salinity surface layer reached a thickness of 20 to $30 \mathrm{~m}$ with values between 3.6 to $23.9 \%$ oo. The surface waters were well oxygenated, 4 to $8 \mathrm{ml} \mathrm{O}_{2} \mathrm{l}^{-1}$, and sometimes supersaturated up to a maximum of $130 \%$. The surface temperature varied between 11.7 and $12.9^{\circ} \mathrm{C}$ with small variation in depth (Silva et al., 1995). Significant changes were observed in temperature and salinity along the fjord, showing variations of density that could have important biological implications for composition and spatial distribution of the macrobenthos, including the polychaetes.

The shallow soft-bottom sediments in Aysen Fjord showed different composition according to the place. In Acantilada Bay the sediments were composed mainly of very coarse sand $(\phi=0)$ and coarse silt $(\phi=5)$ with presence of shell debris at some stations; only at station 2 was the presence of pebbles $(\phi=-4)$ to very coarse sand detected. The organic matter content varied between 1.27 and $9.69 \%$. In Condor River no sample was collected for sediment analyses. In Cuervo River the sediments showed a similar composition to Acantilada Bay (very coarse sand to coarse silt, with a high percentage of fine sand, $30 \%$ ), with a lower percentage of organic matter (1.2 to $2.4 \%)$ than in Acantilada Bay. The depth of the stations was $11 \mathrm{~m}$ in Condor River, where only one station was considered, between 5 to $10 \mathrm{~m}$ in Cuervo River (average $=7 \mathrm{~m}$ ), and between 2 and $26 \mathrm{~m}$ in Acantilada Bay (average $=8 \mathrm{~m}$ ).

Dalcahue Channel is a shallow site (maximum $22 \mathrm{~m}$ depth) located between Chiloé Island and Quinchao Island (Fig. 2a, b), and represents the northern end of the Magellan Province. The stations were located along the middle line of the channel, with station 1 between Quiquel Point (Chiloé Island) and Degan Point (Quinchao Island) (Fig. 2b). The bottom temperature varied between 12.3 and $13.0^{\circ} \mathrm{C}$ and the salinity showed small variation, between 32.3 and $32.4 \%$ (Leighton et al., 1998). The deeper water column is well oxygenated $\left(>7.2 \mathrm{ml} \mathrm{O}_{2} \mathrm{l}^{-1}\right)$, with little variation among stations. Grain size analyses revealed the presence of very coarse sand $(\phi=0)$ to fine sand $(\phi=3)$ with shell debris at stations 4 and 5.

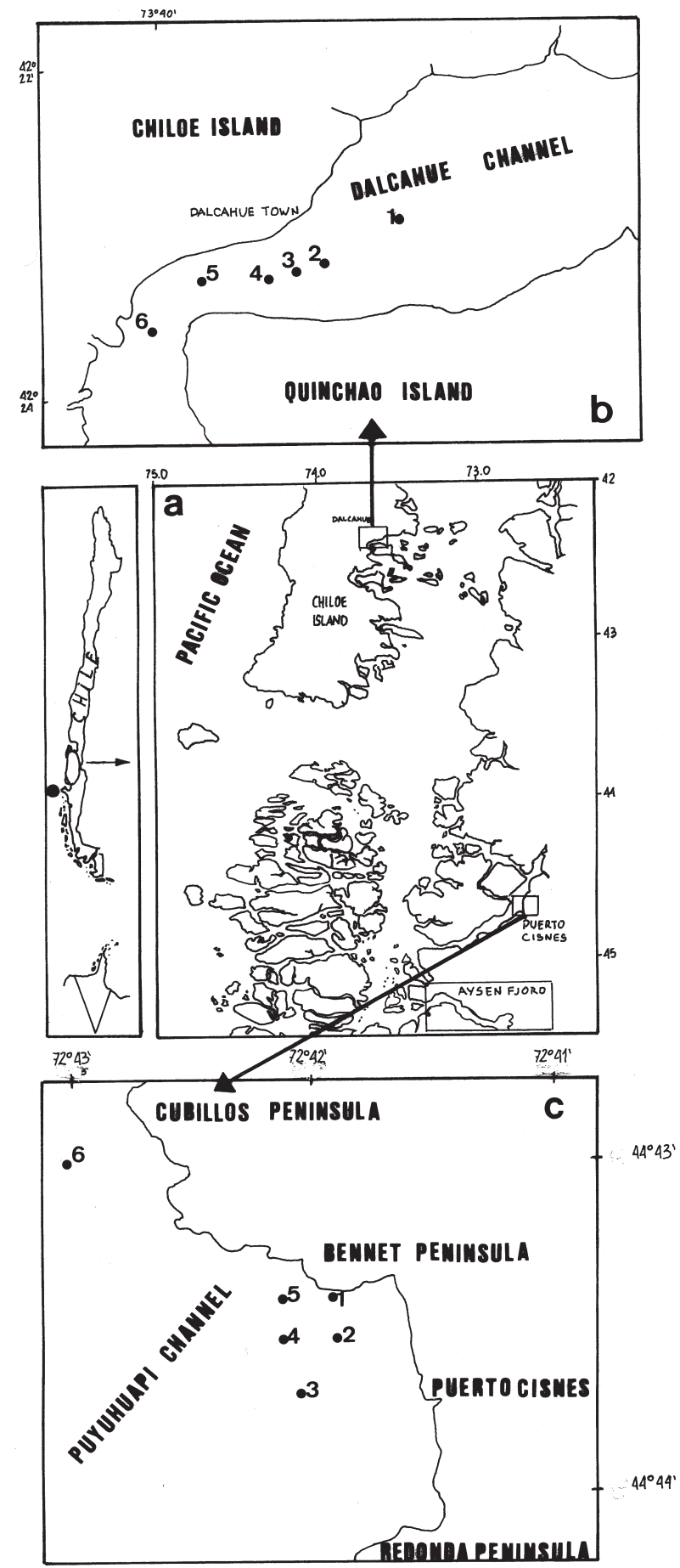

FIG. 2. - a) Map showing Chile, the Straits of Magellan and the geographical position of the three study areas located in the northern part of the Magellan Province. The black circle in the Chilean map shows the Taitao Peninsula. b) Spatial distribution of sampling stations along Dalcahue Channel, Chiloé Island. c) Spatial distribution of sampling stations at Puerto Cisnes, Puyuhuapi Channel.

Puerto Cisnes is located within Puyuhuapi Channel (Fig. 2a, c). Five stations were located between Bennett Point and Redonda Point, while station 6 was located off Cubillos Point (Fig. 2c). At the 
southern end of the channel is the mouth of the Cisnes River which defines the hydrological features of this area (not shown in Fig. 2c). The bottom temperature varied between 10.5 and $11.8^{\circ} \mathrm{C}$ below $15 \mathrm{~m}$ depth, while salinity varied between 30.0 and 31.5\% (Leighton et al., 1997). As in Aysen Fjord, deep waters are well oxygenated with lowest values above $5.3 \mathrm{ml} \mathrm{O}_{2} \mathrm{l}^{-1}$.

In general, the hydrological features at the three sites considered in this study show small variation in terms of oceanography, thus allowing community comparison. The three sites belong to the northern sector of austral fjords as defined by Pickard and Stanton (1980).

The biological material was collected between 21 and 26 September 1995 at three sites along the Aysen Fjord, mouth of rivers Cuervo and Condor and Acantilada Bay (see Fig. 1). The platform of work was the $15 \mathrm{~m}$ boat "Piruca". At each site, the samples were collected using a small grab (WildoEkman bottom dredge; $0.02 \mathrm{~m}^{2}$ ), activated at the bottom by a hooka diver. Three replicates were obtained at each of six or seven sites selected at each location. In Condor River only one station with three replicates was sampled. The samples were fixed in $10 \%$ formalin and preserved in $70^{\circ}$ alcohol. The macrofauna was sieved on a $0.5 \mathrm{~mm}$ mesh screen and the material retained was observed under a stereo microscope. The polychaetes were identified and counted. The references used for identifications were Wesenberg-Lund (1962), HartmannSchröder $(1962,1965)$ and Ehlers (1901). The identification of polychaetes collected at the different sites was carried out by one of the authors (JIC). The samples obtained from Dalcahue and Puyuhuapi Channels were collected during February 13 and 17, 1997, respectively. Three replicates per station were collected at each study site.

Species diversity indices, evenness and dominance were calculated for each site using the abundance as an ecological attribute, being incorporated in software provided in Ludwig and Reynolds (1988). The formulas for each index used were:

Shannon index of diversity (H'):

$$
\mathrm{H}^{\prime}=-\Sigma \mathrm{n}_{\mathrm{i}} / \mathrm{N} \ln \left(\mathrm{n}_{\mathrm{i}} / \mathrm{N}\right) \text { (Shannon and Weaver, }
$$$$
\text { 1949) }
$$

Evenness (J):

$$
\mathrm{J}=\mathrm{H}^{\prime} / \mathrm{H}_{\max }=\mathrm{H}^{\prime} / \ln \mathrm{S} \text { (Pielou, 1977) }
$$

Simpson index (D):

$$
\mathrm{D}=\Sigma\left(\left(\mathrm{n}_{\mathrm{i}}\left(\mathrm{n}_{\mathrm{i}}-1\right) / \mathrm{N}(\mathrm{N}-1)\right)(\text { May, 1981), }\right.
$$

where $\mathrm{n}_{\mathrm{i}}=$ number of individuals in the $\mathrm{i}^{\text {th }}$ species, $\mathrm{N}$ $=$ total number of individuals, and $\mathrm{S}=$ number of species.

The biogeographic analyses were carried out through comparison with benthic studies published in the Magellan area, in particular the Magellan Straits (Fig. 2a), as well as results obtained by us (Leighton et al., 1997, 1998) for Dalcahue and Puerto Cisnes (Fig. 2a-c). The biogeographic comparisons with the Antarctic polychaete fauna were carried out including data published by other authors. The number of common species was used to assess the similarities between the Aysen Fjord polychaete fauna with those of the Magellan Province as well as of Antarctica.

To identify the geographic origin and the affinities of the benthic polychaetes from Aysen Fjord, four categories were used to classify their geographical distribution (Rozbaczylo, 1985):

$\mathrm{a}=$ species present only within the limits of the Magellan Province: south of the Subtropical Convergence $\left(40^{\circ} \mathrm{S}\right)$ and sites located to the north of the Antarctic Convergence $\left(\sim 60^{\circ} \mathrm{S}\right)$

$\mathrm{b}=$ species present along the Chilean coast from Arica $\left(18^{\circ} \mathrm{S}\right)$ to north of the Antarctic Convergence $\mathrm{c}=$ species present in the Magellan Province and sites located to the south of the Antarctic Convergence

$\mathrm{d}=$ species present in $\mathrm{a}, \mathrm{b}$ and $\mathrm{c}$.

\section{RESULTS}

\section{Species composition and abundance}

The benthic polychaetes from shallow marine communities of Aysen Fjord include 38 species belonging to 24 families and 28 genera. Six taxa were identified only to family level, 6 to genus level and 25 to species level. According to the traditional classification in which the polychaetes were separated in the subclasses Errantia and Sedentaria, 22 taxa were found in the Errantia and 16 in the Sedentaria (Table 1). According to the actual scheme of taxonomy classification to the order level, in the Errantia the Phyllodociformia predominate while in Sedentaria there is no predominance. Among the taxa not identified to species level, each family name denotes at least a single taxon. There is a low number of species per family (maximum 3 or 4; families Nereididae and Orbiniidae, respectively). 
TABLE 1. - Composition and abundance of benthic polychaetes of three sites from Aysen Fjord, Chile, collected between September 21 and 25, 1995. Abundance expressed as individuals per $0.02 \mathrm{~m}^{2}$. Cu: Cuervo R.; Co: Condor R; Ac: Acantilada B.

Subclass/Family/Species Stations $\mathrm{Cu} \quad \mathrm{Co} \quad \mathrm{Ac}$

\section{ERRANTIA}

Polynoidae

Harmothoinae undet.

Pholoidae

Pholoe polymorpha (Hartmann-Schröder, 1962) $36 \quad 6 \quad 2$

Amphinomidae

Pseudeurythoe annulata Hartmann-Schröder $\begin{array}{llll}1965 & 0 & 2 & 0\end{array}$

Phyllodocidae

Anaitides longipes (Kingberg, 1866)

Eteone sculpta Ehlers, 1897

Hesionidae

Hesionides arenaria Friedrich, 1937

Syllidae

Syllidae und.

Sphaerosyllis sp.

Nereididae

Namanereis quadraticeps (Blanchard, 1849)

Perinereis gualpensis Jeldes, 1963

Platynereis australis (Schmarda, 1861)

Nepthyidae

Aglaophamus sp.

Aglaophamus macroura (Schmarda, 1861)

Glyceridae

Hemipodus longipapillatus Hartmann-Schröder $1965 \quad 2 \quad 000$

Hemipodus heteropapillatus Hartmann-Schröder 1962442

Goniadidae

Goniadidae und.

Glycinde armata (Kinberg, 1866)

Lumbrineridae

Lumbrineris cingulata (Ehlers, 1897)

Ninoe falklandica Monro, 1936

Arabellidae

Arabella mutans (Chamberlin, 1919)

Dorvilleidae

Schistomeringos longicornis (Ehlers, 1901)

Meiodorvillea chilensis Hartmann-Schröder 1965

\section{SEDENTARIA}

\section{Orbiniidae}

Leitoscoloplos kerguelensis (McIntosh, 1885)

Phylo felix Hartmann-Schröder 1965

Scoloplos sp.

Paraonidae

Aricidea sp. 1

Aricidea sp. 2

Spionidae

Prionospio patagonica Augener, 1923

Spiophanes soederstroemi Hartman, 1953

Cirratulidae

Cirratulidae undet.

Flabelligeridae

Flabelligeridae undet.

Opheliidae

Travisia kerguelensis McIntosh, 1885

Capitellidae

Mediomastus branchiferus Hartmann-Schröder 1962

Capitella sp.

Pectinariidae

Cistenides ehlersi (Hessle, 1917)

Ampharetidae

Sosanides glandularis Hartmann-Schröder 1965

Terebellidae

Terebellidae undet.

Sabellidae

Sabellidae undet.

Number of species

Total Abundance $\begin{array}{lll}1 & 0 & 1 \\ 1 & 0 & 0\end{array}$

$1 \quad 0 \quad 0$

$\begin{array}{lll}2 & 2 & 0 \\ 4 & 1 & 0\end{array}$

$\begin{array}{lll}2 & 2 & 0\end{array}$

$\begin{array}{rrr}2 & 0 & 31 \\ 1 & 0 & 0\end{array}$

200

$\begin{array}{lll}13 & 5 & 10\end{array}$

$\begin{array}{lll}4 & 2 & 1\end{array}$

$\begin{array}{lll}1 & 0 & 0 \\ 1 & 0 & 0\end{array}$

$\begin{array}{rrr}11 & 0 & 0 \\ 0 & 0 & 6\end{array}$

(1)

200

$\begin{array}{lll}5 & 0 & 1 \\ 2 & 1 & 0\end{array}$

$\begin{array}{rrr}22 & 21 & 46 \\ 2 & 0 & 0 \\ 37 & 2 & 0\end{array}$

$\begin{array}{lll}493 & 187 & 159\end{array}$

$\begin{array}{llr}9 & 1 & 2\end{array}$

111732206

$8633 \quad 0$

$82 \quad 10 \quad 20$

100

800

$\begin{array}{lll}13 & 7 & 35\end{array}$

020

$3 \quad 9 \quad 2$

$123 \quad 12 \quad 119$

132

$1 \quad 0 \quad 25$

$\begin{array}{lll}35 & 20 & 17\end{array}$

$1086 \quad 3812668$
A total of 4135 individuals were collected. The spionid Prionospio patagonica was the species with the highest frequency and abundance of all polychaetes, about $57.8 \%$ of the total abundance of polychaetes, mainly in Acantilada Bay. At the other locations the paraonid Aricidea sp. 1 was most abundant. Average abundance ranged from 52 to 148 indiv. $0.02 \mathrm{~m}^{-2}$ (Table 2), while the mean species richness varied between 12 (Acantilada Bay) and 20 species $0.02 \mathrm{~m}^{-2}$ (Acantilada Bay). The number of individuals per species decreased from Acantilada Bay to Cuervo River, as did the mean abundance, while species richness increased (Table 2). The mouth of Cuervo River shows the maximum number of species and Acantilada Bay the lowest (Table 1). In general, the polychaetes were of small size, the pectinariid Cistenides elhersi and the orbiniid Leitoscoloplos kerguelensis being the largest in these communities ( $20 \mathrm{~mm}$ in length).
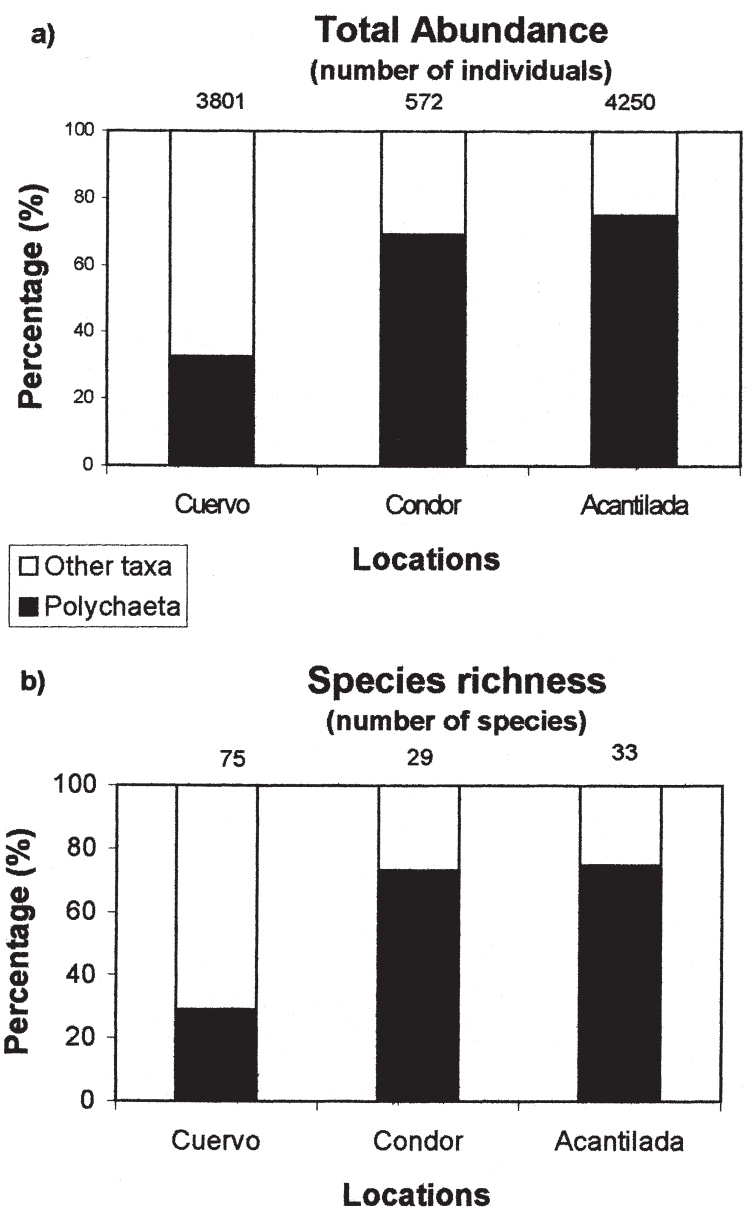

FIG. 3. - Comparison between Polychaeta and other invertebrate taxa collected in shallow, subtidal macrozoobenthos communities from three localities in Aysen Fjord, Chile. Sampling carried out September 21 to 26,1995 . The numbers over each bar represent the total number of individuals or species found at each study site: a ) total abundance, b) number of species. 
TABLE 2. - Comparative analysis of the polychaete fauna of shallow subtidal soft bottom communities of three locations from the Magellan Biogeographical Province. Sampling carried out between 1995 (September; Aysen Fjord) and 1997 (February; Dalcahue and Puerto Cisnes; data from Leighton et al., 1997, 1998). In brackets: coefficient of variation (\%).

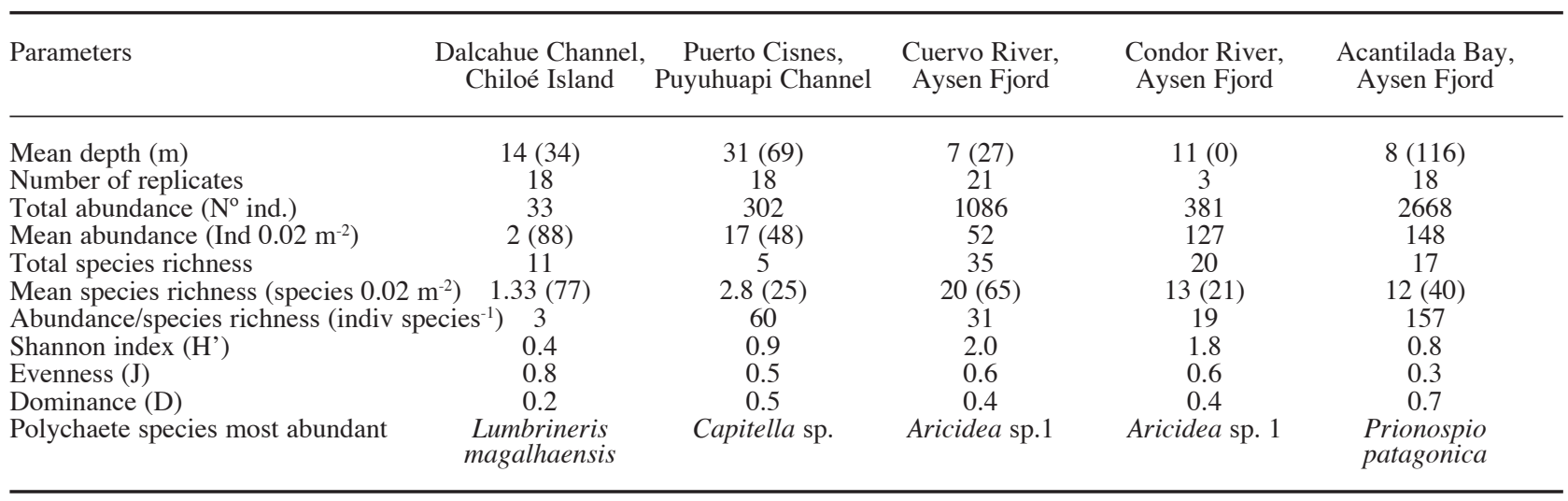

Eleven species were common at the three study sites in Aysen Fjord: Pholoe polymorpha, Aglaophamus macroura, Hemipodus heteropapillatus, Leitoscoloplos kerguelensis, Aricidea spp., Prionospio patagonica, Cirratulidae undet., Cistenides ehlersi, Sosanides glandularis and Terebellidae undet. These species were the most abundant and showed high frequency (Table 1).

The polychaetes were the most abundant taxon within the benthic communities from Aysen Fjord, in particular at the mouth of the Condor River and in Acantilada Bay. At both sites, the richness of species as well as the total abundance were over $55 \%$ of total macrofauna. Only in Cuervo were the polychaetes less important (Fig. 3). Besides Polychaeta, in Cuervo 13 major taxa were identified including Anthozoa, Nemertea, Platyhelminthes, Oligochaeta, Sipunculida, Bivalvia, Polyplacophora, Gastropoda, Nudibranchia, Arthropoda, Echinodermata and Hemichordata. In Condor 7 major taxa were identified: Anthozoa, Nemertea, Oligochaeta, Bivalvia, Gastropoda, Arthropoda and Hemichordata. In Acantilada Bay only 6 higher taxa were collected, namely Anthozoa, Nemertea, Oligochaeta, Bivalvia, Gastropoda and Arthropoda.

A comparison among the three sites shows that in the mouth of Condor River the most abundant polychaete species were Aricidea sp. 1, Prionospio patagonica, Spiophanes soederstroemi and Leitoscoloplos kerguelensis. At this site polychaetes were the most abundant group with 398 individuals and 21 taxa. In the Cuervo River mouth, the polychaetes were predominant only in terms of species richness ( $48 \%$ of the total number); the small paraonid Aricidea sp. 1 being the most abundant. In Acantilada Bay the most representantive taxon in terms of abundance were the polychaetes with 3210 individuals and 17 species. At this site the spionid Prionospio patagonica was the most abundant species (Table 1 and 2).

\section{Biogeographical analyses}

A first comparison of the polychaete fauna within the Magellan Province was carried out with Dalcahue and Puerto Cisnes, both within the limits of the Magellan Province (Moyano, 1982; Brattström and Johanssen, 1983), and both of them channels. There is a latitudinal gradient in terms of abundance and species richness of the polychaetes, the values of Aysen Fjord being highest (Table 2) (Leighton et al., 1997, 1998). In Dalcahue Channel the abundance and species richness are two or three orders of magnitude less than in Aysen Fjord and the parameters related with diversity show lowest values respect to Aysen Fjord. Seven species were common to Dalcahue and/or Puerto Cisnes and the Aysen Fjord locations; these species are: Eteone sculpta, Syllidae undet., Perinereis gualpensis, Platynereis australis, Aglaophamus macroura, Hemipodus longipapillatus and Prionospio patagonica.

A second comparison was done with published data obtained in the Magellan Straits. There are few reports about the shallow associations of polychaetes from the Magellan Straits. According to a list of polychaete taxa found during the Italian Campaign in the Straits of Magellan in February and March 1991 (Gambi and Mariani, 1997) there are only five common species between the latter and Aysen Fjord. The species are: Leitoscoloplos kerguelensis, Phylo felix, Glycinde armata, Lumbrineris cingulata and Cistenides elhersi (Table 2). How- 
TABLE 3. - Comparative analyses of the polychaete fauna from shallow subtidal soft bottom communities in Antarctica with Aysen Fjord, Chile. ns $=$ not shown. ${ }^{*}$ represents mean of the three sites indicated in Table 2.

\begin{tabular}{|c|c|c|c|c|c|}
\hline Parameters & $\begin{array}{l}\text { Admiralty Bay, } \\
\text { King George Island }\end{array}$ & $\begin{array}{l}\text { Terra Nova Bay, S } \\
\text { Ross Sea }\end{array}$ & $\begin{array}{l}\text { Southeastern Weddell } \\
\text { Sea shelf }\end{array}$ & $\begin{array}{l}\text { Chile Bay, } \\
\text { Greenwich Island }\end{array}$ & Aysen Fjord (*) \\
\hline Mean abundance (Ind. $\mathrm{m}^{-2}$ ) & $60-3300$ & $40-12000$ & $26-5593$ & ns & 5450 \\
\hline Total species richness & 25 & 77 & ns & 206 & 38 \\
\hline Number of polychaete families & 17 & 24 & ns & 26 & 24 \\
\hline Common species with Aysen fjord & 2 & 1 & ns & 3 & - \\
\hline Mean species richness (species $\mathrm{m}^{-2}$ ) & 11 & $2-40$ & ns & ns & 15 \\
\hline Shannon index $\left(\mathrm{H}^{\prime}\right)$ & $0.2-2.4$ & $0.2-4.0$ & ns & ns & 1.5 \\
\hline Evenness (J') & $0.1-0.9$ & $0.05-1.00$ & ns & ns & 0.5 \\
\hline \multicolumn{6}{|c|}{ Polychaete species most abundant (>50\%) } \\
\hline within the taxon & $\begin{array}{c}\text { Capitella capitata } \\
\text { Scoloplos } \\
\text { marginatus }\end{array}$ & $\begin{array}{l}\text { Tharyx cincinnatus } \\
\text { Spiophanes tcherniai }\end{array}$ & ns & $\begin{array}{l}\text { Maldane sarsi } \\
\text { Tharyx cincinnatus }\end{array}$ & $\begin{array}{l}\text { Aricidea sp. } 1 \\
\text { Prionospio } \\
\text { patagonica }\end{array}$ \\
\hline Reference & $\begin{array}{c}\text { Sicinski \& Janowska, } \\
1993\end{array}$ & $\begin{array}{l}\text { Gambi et al., } \\
1997\end{array}$ & Gerdes et al., 1992 & $\begin{array}{c}\text { Gallardo et al., } \\
1988\end{array}$ & Present study \\
\hline
\end{tabular}

ever, many of the taxa were identified by Gambi and Mariani (1997) to genus level only.

\section{Biogeographical affinities with the Antarctic polychaete fauna}

In order to assess biological affinities between the polychaete fauna from Aysen Fjord with Antarctica, several ecological parameters were compared with the literature available: the number of common species, the mean abundance, the richness of species and the Shannon index of diversity when possible. It is observed that the Aysen Fjord polychaete fauna has a low number of common species with Antarctica (L. kerguelensis, A. macroura, L. cingulata, $P$. felix and $S$. soederstroemi), except Chile Bay (Greenwich Island), although the total richness of species, the mean richness, and the number of families present similarity in the values. With the exception of Terra Nova Bay, the mean abundance of polychaetes is close to the values detected in the Antarctic benthos (Table 3). The Shannon index of diversity shows that the biodiversity of Aysen Fjord is similar to that reported for shallow benthic communities from Admiralty Bay and Terra Nova Bay (Table 3), in particular for depths less than $30 \mathrm{~m}$.

\section{Geographical origin of the benthic polychaetes from Aysen Fjord}

In relation to the geographical origin of the benthic polychaetes from Aysen Fjord identified to specific level it is observed that eleven species are found between Arica, northern limit of Chile, and the limit of the Antarctic Convergence; three species are found between Arica and Antarctica; one species
TABLE 4. - Composition of benthic polychaetes from Aysen Fjord in relation to geographical origin (geographical distribution based on Rozbaczylo, 1985). Categories are: a, species present only within the limits of the Magellan Province: Subtropical Convergence $\left(40^{\circ} \mathrm{S}\right)$ and sites located to the north of the Antarctic Convergence $\left(\sim 60^{\circ} \mathrm{S}\right) ; \mathrm{b}$, species present along the Chilean coast from Arica $\left(18^{\circ} \mathrm{S}\right)$ to north of the Antarctic Convergence; $\mathbf{c}$, species present in the Magellan Province and Antarctica (sites located to the south to the Antarctic Convergence); d, species present in a, b and c.

\begin{tabular}{cccc}
\hline a $(\mathbf{N}=\mathbf{9})$ & $\mathbf{b}(\mathbf{N}=\mathbf{1 1})$ & $\mathbf{c}(\mathbf{N}=\mathbf{1})$ & $\mathbf{d}(\mathbf{N}=\mathbf{4})$ \\
\hline P. annulata & P. polymorpha & A. macroura & $\begin{array}{c}\text { A. longipes } \\
\text { E. sculpta }\end{array}$ \\
N. quadraticeps & H. arenaria & L. kerguelensis \\
G. armata & P. gualpensis & S. soederstroemi \\
N. falklandica & P. australis & \\
S. longicornis & H. longipapillatus & \\
M. chilensis & H. heteropapillatus & \\
P. felix & L. cingulata & \\
T. kerguelensis & A. mutans & \\
C. elhersi & P. patagonica & \\
& M. branchiferus & \\
& S. glandularis & \\
\hline
\end{tabular}

is restricted to the Magellan Province and the Antarctic, and nine species are restricted to the Magellan Province (Table 4). Within these nine species, at least four species are present in other areas such as New Zealand ( $N$. quadraticeps, $P$. australis and A. macroura), southwestern Australia (P. australis and A. macroura) and southern Africa (A. longipes).

\section{DISCUSSION}

The present study shows that the Aysen Fjord polychaete fauna comprises 38 species. Polychaetes are the most representative taxon in terms of abundance and species richness in two of the three sites sampled (Fig. 3). This situation seems to be common in other sites of the Magellan Province such as 
in Campos de Hielo Sur ( $45^{\circ}$ to $53^{\circ} \mathrm{S}$ ) (Mutschke et al., 1996) and the Beagle Channel (Arntz and Gorny, 1996), although the importance of the polychaetes decreases towards the northern limit of the Magellan Province, showing low number of species and reduced abundance in Dalcahue and Puerto Cisnes (Leighton et al., 1997, 1998) (Table 2). In addition to a latitudinal pattern in abundance and richness of species, an east-west zonation was detected along the Aysen Fjord in terms of mean abundance and species richness (Table 2). According to Sievers and Prado-Fiedler (1994), significant changes are observed in the oceanographic parameters such as temperature, salinity and density from Acantilada Bay to Cuervo River, possibly causing biological gradients in benthic communities. According to the salinity, the benthic polychaetes of shallow bottoms from Aysen Fjord as well as the other two locations (Puerto Cisnes and Dalcahue Channel) could be considered as typical of estuarine environments with well oxygenated waters.

In relation to the role of the Cape Horn Current (CHC) in contributing to the ecological and biogeographical aspects of the shallow-water benthic polychaetes of the three study sites located along of the northern end of the Magellan Province, important differences in composition, abundance and diversity were observed. A latitudinal gradient is observed from Dalcahue to Aysen Fjord showing an increment in species richness, diversity and abundance towards the south (Table 2). This pattern could be explained by the mix of species living north of the Subtropical Convergence with those of Subantarctic origin in Aysen Fjord (Table 4). On local scale, comparing Aysen Fjord with the channels (Puyuhuapi and Dalcahue), it seems as though the benthic polychaetes were less important in the channels in comparison to other taxa. This situation seems to be caused by the strong currents produced by great tidal changes and the reduced accumulation of fine sediments and organic matter at the bottom (Leighton et al., 1997, 1998).

The total number of species from Aysen Fjord is lower than that in the Magellan Straits where 118 species have been reported (Gambi and Mariani, 1997). This difference may be related to the smaller depth range investigated in the present study as well as the different types of sampling gear used.

A reduced number of common species were detected between Aysen Fjord and the Magellan Straits (Gambi and Mariani, 1997). Viviani (1969; fide Moyano, 1982), taking into account littoral Bry- ozoa, considered the southern end of Chile as two subprovinces of the Magellan area: northern Patagonica $\left(40^{\circ} \mathrm{S}-46^{\circ} \mathrm{S}\right)$ and southern Patagonica $\left(46^{\circ} \mathrm{S}\right.$ $\left.56^{\circ} \mathrm{S}\right)$. Considering the high number of common species between Dalcahue and Puerto Cisnes and the low overlap of the polychaete fauna of these sites with the Magellan Straits (Table 2 and 4), the hypothesis of Viviani (op. cit.) seems to be supported by our data. This pattern is also observed in other taxa such as anthozoans, gastropods, bivalves, asteroids and holothurians (Brattström and Johanssen, 1983). Brattström and Johanssen (1983) indicate that the Taitao Peninsula $\left(\sim 46^{\circ} \mathrm{S}\right)$ is the main barrier to the fauna of both areas (Fig. 2a).

After more than 20 million years of separation between South America and the Antarctic continent there are, however, basic differences in species and family composition of polychaetes in shallow, soft bottom, benthic communities. This holds true, particularly, for the absence of some families of polychaetes common and rich in species in the Antarctic such as Polynoidae, Euphrosinidae and Maldanidae. Other differences between Antarctic and Aysen polychaetes are the size and the low number of species per genus, indicating a poor potential of evolutionary radiation at the Aysen coast. Coincidence of the values of ecological parameters such as abundance and diversity in Antarctica and in Aysen Fjord (Table 3) demonstrate that the benthic polychaetes seem to occupy a similar role in both biogeographical regions. Studies carried out in the Weddell Sea and the Beagle Channel revealed that polychaete abundance contribute to 47 and $62 \%$ of the total abundance of the macrobenthic communities, respectively (Arntz and Gorny, 1996), values that are within the ranges observed in Aysen Fjord.

Scarce affinities in the polychaete fauna exist between Antarctica and the northern sites of the Magellan Province, with only five common species (categories c and d; Table 4). This situation is similar to that of other marine taxa of the Magellan Province such as decapod crustaceans, gastropods and crinoids (Arntz and Ríos, 1997). The benthic polychaetes from Aysen Fjord show low affinities with the Antarctic polychaetes of shallow soft bottoms (Table 4). The maximum number of common species was observed with Chile Bay, Greenwich Island (Gallardo et al., 1988), Antarctic Peninsula. In contrast, lowest overlap values were recorded with locations in the Ross and the Weddell Seas (Gerdes et al., 1992; Sicinski and Janowska, 1993; Gambi et al., 1997). 
The polychaetes collected in Aysen Fjord and reported from Antarctica show wide bathymetric distributions, some species being collected up to $4000 \mathrm{~m}$ depth (e.g. Leitoscoloplos kerguelensis), although most common species are distributed to $600 \mathrm{~m}$ depth (Rozbaczylo, 1985). The invasion of marine Antarctic fauna to more northerly latitudes via great depths has been considered as a potential mechanism of colonizing the southern end of South America (Briggs, 1974).

The identification to specific level of some polychaetes collected in this study, as well as those collected on various national and international expeditions to the Magellan Province, will be necessary to improve our biogeographic knowledge about this taxon and of the degree of endemism in this Province, and to eventually establish the biological relationship between different sites of the Magellan Province and the Antarctic continent.

\section{ACKNOWLEDGEMENTS}

The authors thank the crew of the boat "Piruca" for their patience and collaboration in the field work. The first author wishes to thank Dr. Wolf Arntz (Alfred Wegener Institute, Germany) for a special invitation to the congress and financial support obtained through fellowship by the Intergovernamental Oceanographic Commission of UNESCO. The first author thanks Dr. M.C. Gambi (Stazione Zoologica "A. Dohrn", Napoli, Italia) and two anonymous referees for their important comments. A special mention goes to the Departamento de Ciencias y Recursos Naturales, Universidad de Magallanes, and to the Instituto de Oceanología, Universidad de Valparaiso, Chile, for technical support to finish this manuscript.

\section{REFERENCES}

Arntz, W.E., T. Brey and V.A. Gallardo. - 1994. Antarctic zoobenthos. Oceanogr. Mar. Biol. Ann. Rev., 32: 241-303.

Arntz, W. and M. Gorny. - 1996. Cruise Report of the Joint Chilean-German-Italian Magellan ,Victor Hensen“ Campaign in 1994. Ber. Polarforsch., 190: 1-113.

Arntz, W. and C. Ríos. - 1997. Abstracts presented in the International Congress "Marine biological research in the Magellan region related to the Antarctic", April 7-11, 1997, Punta Arenas, Chile.

Avaria, S., D. Cassis, P. Muñoz and P. Vera. - 1996. Distribución del microfitoplancton en aguas interiores del sur de Chile. In: Comité Oceanográfico Nacional (ed.), Results of the cruise CIMAR-FIORDO 1, pp. 76-81. CONA, Valparaíso.

Brattström, H. and A. Johanssen. - 1983. Ecological and regional zoogeography of the marine benthic fauna of Chile. Report $\mathrm{N}^{\circ}$
49 of the Lund University Chile Expedition 1948-49, Sarsia, 68: 233-339.

Briggs, J.C. - 1974. Marine Zoogeography. McGraw Hill Book Co., New York.

Ehlers, E. - 1901. Die Polychaeten des magellanischen und chilenischen Strandes. Ein faunistischer Versuch. Festschrift zur Feier des Hundertfünfzigjährigen Bestehens der Königlichen Gesellschaft der Wissenschaften zu Göttingen, pp. 1-232. Wiedmannsche Buchhandlung, Berlin.

Gallardo, V.A., S. Medrano and F.D. Carrasco. - 1988. Taxonomic composition of the sublittoral soft-bottom Polychaeta of Chile Bay (Greenwich Island, South Shetland Islands, Antarctica). Ser. Cient., INACH, Chile, 37: 49-67.

Gambi, M.C., A. Castelli and M. Guizzardi. - 1997. Polychaete populations of the shallow soft bottoms off Terra Nova Bay (Ross Sea, Antarctica): distribution, diversity and biomass. Polar Biol., 17: 199-210.

Gambi, M.C. and S. Mariani. - 1997. Polychaetes of the soft bottoms of the Strait of Magellan (South America) collected during the Italian Oceanographic campaign in February-March 1991. In: W. Arntz and C. Ríos (eds.), Abstracts presented in the International Congress "Marine Biological Research in the Magellan Region related to the Antarctic”, April 7-11, 1997, Punta Arenas, Chile.

Gerdes, D., M. Klages, W. E. Arntz, R.L. Herman, J. Galéron and S. Hain. - 1992. Quantitative investigations on macrobenthos communities of the southeastern Weddell Sea shelf based on multibox corer samples. Polar Biol., 12: 291-301.

Hartmann-Schröder, G. - 1962. Zur Kenntnis des Eulitorals der chilenischen Pazifikküste und der argentinischen Küste Südpatagoniens unter besonderer Berücksichtigung der Polychaeten und Ostracoden. Tl. II. Die Polychaeten des Eulitorals. Mitt. Hamburg. Zool. Mus. Inst., 60: 57-167.

Hartmann-Schröder, G. - 1965. Zur Kenntnis des Sublitorals der chilenischen Küste unter besonderer Berücksichtigung der Polychaeten und Ostracoden. Tl. II. Die Polychaeten des Sublitorals. Mitt. Hamburg. Zool. Mus. Inst., 62: 59-305.

Leighton, G, R. Prado and B. Malet. - 1994. Programa mínimo de evaluación de impactos ambientales de algunas industrias pesqueras que vierten en el canal de Yal, comuna de Chonchi, Isla de Chiloé, X Región. Inf. Cient. Técn. de Avance, Inst. Oceanol., Univ. Valparaíso, 013/92: 1-50.

Leighton, G., R. Prado, H. Sievers, J.I. Cañete and L. López. 1997. Estudio ecológico ambiental del área de Puerto Cisnes, XI Región. Inf. Cient. Técn., Inst. Oceanol., Univ. Valparaíso, 012/97: 1-89.

Leighton, G., R. Prado, H. Sievers, J.I. Cañete and L. López. 1998. Estudio impacto ambiental planta pesquera de Agromar S.A. en Dalcahue, X Región. Inf. Cient. Técn., Inst. Oceanol., Univ. Valparaíso, 01/98: 1- 60.

Ludwig, J.A. and J.F. Reynolds. - 1988. Statistical Ecology. A Primer on Methods and Computing. John Wiley and Sons, Inc., New York.

May, R.M. - 1981. Patterns in multi-species communities. In: R. M. May (ed.): Theoretical Ecology, pp. 197-227. Sinauer Association, Sunderland, Massachussettes.

Moyano, H.I. - 1982. Magellanic Bryozoa: some ecological and zoogeographical aspects. Mar. Biol., 67: 81-96.

Mutschke, E., C. Ríos, T. Hromic and M. Gorny. - 1996. Estudios bentónicos en fiordos y canales de los Campos de Hielo Sur $\left(45^{\circ}-53^{\circ} \mathrm{S}\right)$. In: Comité Oceanográfico Nacional (ed.), Results of the cruise CIMAR-FIORDO 2, pp. 91-98. CONA, Valparaíso.

Pickard, G.L. and B.R. Stanton. - 1980. Pacific fjords. A review of their water characteristics. In: H. J. Freeland, D. M. Farmer and C. D. Levings (eds.), Fjord Oceanography, pp. 1-51. NATO Conf. Ser., Vol. 4. Marine Science Plenum Press, New York.

Pielou, E.C. - 1977. Mathematical Ecology. John Wiley and Sons, New York.

Rozbaczylo, N. - 1985. Los anélidos poliquetos de Chile. Indice sinonímico y distribución geográfica de especies. Monogr. Biol., Pontificia Univ. Catól. Chile, 3: 1-284.

Rozbaczylo, N., C. Ríos and E. Mutschke. - 1997. Poliquetos de la región de Magallanes: estado actual de su conocimiento a través de un análisis histórico y un estudio de caso. In: W. Arntz and C. Ríos (eds.), Abstracts presented in the International Congress „Marine Biological Research in the Magellan Region related to the Antarctic", April 7-11, 1997, Punta Arenas, Chile. 
Shannon, C.E. and W. Weaver. - 1949. The Mathematical Theory of Communication. University Illinois Press, Urbana, Illinois.

Sicinski, J. and E. Janowska. - 1993. Polychaetes of the shallow sublittoral of Admiralty Bay, King George Island, South Shetland Islands. Antart. Sci., 5: 161-167.

Sievers, H. and R. Prado-Fiedler. - 1994. Contraste de las características oceanográficas del seno Aysén, Chile, entre invierno y verano (Lat. 45'20' S). Rev. Biol. Mar., Valparaíso, 29: 167-209.

Sievers, H. and A. Vega. - 1996. Distribución de características físico-químicas del agua de mar en canales y fiordos de las regiones X-XI. In: Comité Oceanográfico Nacional (ed.), Results of the cruise CIMAR-FIORDO 1, Chile, pp. 28-30. CONA, Valparaíso.

Silva, N., H.A. Sievers and R. Prado. - 1995. Características oceanográficas y una proposición de circulación para algunos canales australes de Chile entre $41^{\circ} 20^{\prime}$ S y $46^{\circ} 40^{\prime}$ S. Rev. Biol. Mar., Valparaíso, 30: 207-254.

Wesenberg-Lund, E. - 1962. Polychaeta Errantia. Rep. Lund Univ. Chile Exped. 43. Acta Univ. Lund, 57(12): 1-139 